\title{
MIGRATION INTENTIONS OF GHANAIAN MEDICAL STUDENTS: THE INFLUENCE OF EXISTING FUNDING MECHANISMS OF MEDICAL EDUCATION ("THE FEE FACTOR")
}

\author{
S. ELIASON ${ }^{1}$, D. A. TUOYIRE ${ }^{3}$, C. AWUSI-NTI ${ }^{2}$ and A. S. BOCKARIE ${ }^{1}$ \\ ${ }^{1}$ Department of Community Medicine, School of Medical Science, University of Cape Coast, Cape Coast, \\ Ghana ${ }^{2}$ Department of Obstetrics and Gynaecology, Cape Coast Teaching Hospital, Cape Coast, Ghana \\ ${ }^{3}$ School of Medical Sciences, University of Cape Coast, Cape Coast, Ghana
}

DOI: http://dx.doi.org/10.4314/gmj.v48i2.4

Corresponding Author: Dr. Sebastian Eliason

Email:s.eliason@uccsms.edu.gh, sakeliason@yahoo.co.uk

Conflict of Interest: None declared

\section{SUMMARY}

Background: To explore the effects of fee paying status on migration intentions of Ghanaian medical students.

Design: Cross sectional questionnaire based survey

Setting: All established Ghanaian medical schools with students in their clinical years

Participants: Fee-paying and non-fee-paying Ghanaian medical students in their clinical years

Interventions: None

Main outcome measures: Migration intentions of Ghanaian medical students after graduation, Allegiance to Government of Ghana

Results: Approximately half (49\%) of the medical students surveyed had intentions of migrating after school. Over $48 \%$ of those with migration intentions plan on doing so immediately after completing their house job, while $44 \%$ plan to migrate at least one year after their house job. The most popular destination chosen by the potential migrant doctors was North America $(38 \%)$. Fee-paying students were significantly more likely $(\mathrm{OR}=2.11, \mathrm{CI}=1.32,3.38)$ than non-fee-paying students to have intentions of migrating after their training. Secondly, fee-paying students were more likely $(\mathrm{OR}=9.66, \mathrm{CI}=4.42,21.12)$ than non-fee paying students to feel they owe no allegiance to the Government of Ghana because of their fee-paying status.

Conclusions: Medical Students' fee-paying status affects their intentions to migrate and their allegiance to the country after completion of their training.

Keywords: Migration intention, fee paying, medical students, allegiance

\section{INTRODUCTION}

The current wave of international migration of doctors has a longer history to it than can be acknowledged ${ }^{1}$. It has become even more pronounced as a result of rapid globalization, where doctors leave in search of better pay, better working conditions, professional development and better life for their families. ${ }^{2}$ The issue of migration of health personnel, especially doctors, was recognized by the World Health Organization (WHO) as a global setback during the world health assembly in 2005 , to the extent that they included human resources for health development as a top-priority area in their Programme of Work 2006-2015. ${ }^{3}$ The WHO sponsored Global Health Work Alliance estimates that 1 in 4 doctors will leave Africa to pursue higher-paying jobs abroad. $^{4}$

Migration of doctors is not a new phenomenon in Ghana. The country lost $60 \%$ of its medical doctors in the 1980 s and approximately 600 to 700 Ghanaian physicians were practicing in the USA alone at the time, a figure that represented roughly $50 \%$ of the total population of doctors in Ghana. ${ }^{5}$ Between 1986 and 1995, $61 \%$ of the output of one medical school in Ghana had left the country mostly to the United Kingdom and USA $^{6}$, amounting to a loss of USD 5.96 Million in tuition fees to the country. ${ }^{7}$ Statistics from the Government of Ghana (GOG) sources indicate that $31 \%$ of health professionals, including six hundred (600) doctors left the country between 1993 and 2002. These historical trends made the Ministry of Health (MOH) estimate that by 2006 Ghana would experience a shortfall of 1,800 doctors. ${ }^{8}$

Factors influencing migration have generally been grouped into 'Push factors' (i.e. factors that drive people away to the so called richer countries) and 'Pull factors' (i.e. factors that lure people to move to the developed countries). 
The push factors include: delay/lack of promotion prospects, poor management, heavy workload, lack of facilities, a declining health service, inadequate living conditions, high levels of violence and crime, poorly structured local postgraduate program and lack of incentives for hard work. The pull factors include: Better remuneration, Upgrading qualifications, gaining experience, a safer environment and family-related matters (family living abroad).$^{9}$ Research has shown that Ghanaian health personnel intending to migrate will do so: to gain experience, to find better living conditions, to save money quickly to buy a car and build a house, to upgrade professional skills and for better remuneration. $^{10}$

One phenomenon that is gradually emerging in Ghana as a potential "Push factor" is the "FEE factor". The cost of supporting a Ghanaian medical student is very high. Prior to 1998, medical training had been free and entirely sponsored by the government. The government paid for tuition, boarding and lodging, transport and utilities as well as other costs of running the schools. A book and living expenses soft loan was provided by the Social Security and National insurance trust (SSNIT). ${ }^{8}$

From 1998, a cost-sharing program was instituted by the government of Ghana whereby regular or non-feepaying Ghanaian students (defined as those who met the competitive departmental requirements and cut-off points) paid living and other educational expenses except tuition and other educational funding, which were borne by government. Fee-paying Ghanaian students (defined as those who met the minimum university requirements for the course but did not make the competitive departmental requirements and cut-off points) paid full fees including tuition.

Available figures from the 2008/2009 academic year showed that fees paid by tertiary Ghanaian students ranged from four hundred and ten Ghana Cedis (GH\&410) per year for non-fee-paying students to about one thousand, seven hundred Ghana Cedis $(\mathrm{GH} \notin 1,700)$ per year for fee-paying students. Foreign or private students who qualified, paid fees in full (up to $\mathrm{GH} \notin 3,300){ }^{11}$

The cost of higher education, especially medical education has increased over time. At the University of Ghana Medical School (UGMS), non-fee-paying (regular) students currently pay between $\mathrm{GH} \propto 940$ and $\mathrm{GH} \not 1,300$ per annum to support government, whilst the feepaying students pay between $\mathrm{GH} \notin 4,059$ and $\mathrm{GH} \notin 4,387$ as full fees. Students of a recently introduced graduate entry medical program (fee-paying) in UGMS also pay $\mathrm{GH} \notin 13,856$ as full fees. ${ }^{12}$
At the Kwame Nkrumah University of Science and Technology School of Medical Sciences, fees range between GH $₫ 824$ and GH $₫ 873$ for non-fee-Paying students, whilst that for fee-paying students range between $\mathrm{GH} \notin 2012$ and $\mathrm{GH} \notin 7,000$ per annum depending on the level. ${ }^{13}$ The fees for the University for Development Studies range from $\mathrm{GH} \notin 599$ to $\mathrm{GH} \notin 1,358$ per annum depending on the level of student. Foreign and private students paid between $\mathrm{GH} \propto 14,950$ to $\mathrm{GH} \propto$ 21,850 per annum. ${ }^{14}$ The University of Cape Coast School of Medical Sciences is strictly fee-paying. The continuing students paid GHф6,391 whilst freshmen paid GHф6,764. ${ }^{15}$ These fee paying schedules, for average Ghanaians, with grossly inadequate salaries and benefits, are not inexpensive. The fee-paying and some non-fee-paying students may have the feeling that they do not owe any allegiance to the country, and may want to emigrate to greener pastures to recoup the monies spent on their education. Anecdotal evidence suggests that the fee- paying phenomenon may worsen the already bad physician migration situation.

The aim of this study is to explore the effect of feepaying status on migration intentions of Ghanaian medical students. In that respect, two main hypotheses were postulated for testing: (1) fee- paying medical students are significantly more likely than their non-fee-paying counterparts to have intentions of migrating after their training and, (2) fee paying medical students are significantly more likely than their non-fee paying counterparts to feel they owe no allegiance to the country based on their fee-paying status. The view is that feepaying as a mechanism of funding medical training might as well be an important determinant of migration decisions of medical doctors. Understanding the impact of fee-paying status on migration of medical doctors will therefore contribute to the development of a new generation of interventions to prevent exodus of medical doctors.

\section{METHODS}

A survey was conducted from November to January 2012, involving all fee-paying and non-fee-paying Ghanaian clinical students in levels 400, 500 and 600 from all the four public medical schools in Ghana, namely: University of Ghana Medical School (UGMS), Accra; Kwame Nkrumah University of Science and Technology School of Medical Sciences (KNUST SMS), Kumasi; University for Development Studies School of Medical and Health Sciences (UDS SMHS), Tamale; and University of Cape Coast School of Medical Sciences (UCC SMS) Cape Coast. Foreign nationals and pre-clinical students were excluded from the study. Lists of all targeted population of medical students were obtained from the various schools. 
With the help of three focal persons in each of the schools, students were traced to their hostels or lecture rooms. Once the students were met, the objectives of the research were explained to them and their consent sought. As many who were available within the period of the study, and consented, were included in the study. A total of 393 available and consenting medical students consisting of 181 fee-paying and 212 non-fee paying students were recruited into the study.

Participants were asked to complete a 15 minute survey questionnaire consisting of closed and open ended questions designed to elicit information including socio-demographic information, educational sponsorship and migration intentions among others. The survey and protocol were reviewed and approved by the University of Cape Coast, School of Medical Sciences.

Approval was also sought from the Deans of the various medical schools before the commencement of the study. The data was entered using SPSS software and exported to STATA for further processing and analysis. Descriptive statistics were used to describe the background characteristics of the sample and the relationship between each background characteristic and the migration intentions of the medical students.

The two main hypotheses for the study were tested using binary logistic regression, since each dependent variable of interest was constructed as a binary outcome. The dependent variable for the first hypothesis was derived from the question "Do you intend migrating outside of the county after medical school?" Those who responded "Yes" were coded 1 and 0 otherwise.

In a similar manner, the dependent variable of interest for the second hypothesis was derived from the question "Does your payment status make you feel you owe allegiance to the government of Ghana?" All "Yes" responses were coded as 0 while "No" responses were coded 1. Two successive logistic regression models were run in order to test each hypothesis while controlling for the effect of other mediators. The HosmerLemeshow goodness-of-fit test was used to test the fitness of the data for each model.

\section{RESULTS}

\section{Background characteristics of respondents}

The mean age for the sample was $23.3 \pm 2.2$ and $24.6 \pm$ 3.6 for men and women respectively. As shown in Table 1, majority of participants were younger than 25 years, with a greater proportion of men (74\%) compared with women $(71 \%)$.
Table 1 Background characteristics of respondents

\begin{tabular}{|c|c|c|c|c|}
\hline \multirow{2}{*}{ Characteristics } & \multicolumn{2}{|c|}{$\operatorname{Men}(n=211)$} & \multicolumn{2}{|c|}{ Women $(n=182)$} \\
\hline & $\begin{array}{l}\text { Fre- } \\
\text { quency }\end{array}$ & $\%$ & $\begin{array}{l}\text { Fre- } \\
\text { quency }\end{array}$ & $\%$ \\
\hline \multicolumn{5}{|l|}{ Age* } \\
\hline $20-24$ & 149 & 73.7 & 125 & 71.4 \\
\hline $25-29$ & 47 & 23.2 & 47 & 26.9 \\
\hline $30+$ & 6 & 3.1 & 3 & 1.7 \\
\hline Total & 202 & 100 & 175 & 100 \\
\hline \multicolumn{5}{|l|}{ Marital status } \\
\hline Single & 200 & 94.8 & 160 & 87.9 \\
\hline Married & 11 & 5.2 & 22 & 12.1 \\
\hline Total & 211 & 100 & 182 & 100 \\
\hline \multicolumn{5}{|l|}{ Medical school } \\
\hline UG MS & 69 & 32.7 & 50 & 27.5 \\
\hline KNUST SMS & 52 & 24.6 & 55 & 30.2 \\
\hline UDS SMHS & 49 & 23.2 & 33 & 18.1 \\
\hline UCC SMS & 41 & 19.4 & 44 & 24.2 \\
\hline Total & 211 & 100 & 182 & 100 \\
\hline \multicolumn{5}{|l|}{ Level } \\
\hline 400 & 86 & 40.8 & 67 & 36.8 \\
\hline 500 & 61 & 28.9 & 51 & 28.0 \\
\hline 600 & 64 & 30.3 & 64 & 35.2 \\
\hline Total & 211 & 100 & 182 & 100 \\
\hline \multicolumn{5}{|l|}{ Fee Status } \\
\hline Non fee paying & 119 & 56.4 & 93 & 51.1 \\
\hline Fee paying & 92 & 43.6 & 89 & 48.9 \\
\hline Total & 211 & 100 & 182 & 100 \\
\hline \multicolumn{5}{|l|}{ Sponsor } \\
\hline Self & 5 & 2.4 & 3 & 1.7 \\
\hline Guardian & 23 & 10.9 & 13 & 7.1 \\
\hline Parents & 165 & 78.2 & 158 & 86.8 \\
\hline Other & 18 & 8.5 & 8 & 4.4 \\
\hline Total & 211 & 100 & 182 & 100 \\
\hline \multicolumn{5}{|l|}{$\begin{array}{l}\text { Allegiance to } \\
\text { government } *\end{array}$} \\
\hline No & 164 & 78.5 & 157 & 86.3 \\
\hline Yes & 45 & 21.5 & 25 & 13.7 \\
\hline Total & 209 & 100 & 182 & 100 \\
\hline
\end{tabular}

Source: Fieldwork, 2012

* The ' $\mathrm{n}$ ' for characteristic excludes cases with missing information

The majority of the respondents (95\%, men and $88 \%$, women) were single, whilst a greater proportion consisted of men from UGMS (33\%) and women from KNUST (30\%). Level 400students dominated the sample $(38.9 \%)$ followed by those in level 600 (32.5\%). A little over half of the participants $(53.9 \%)$ were non-fee paying students while the others were fee-paying. While men constituted the majority $(56 \%)$ among the non-fee paying students, women (49\%) dominated the fee-paying students. 
Parents were the major sponsors of the medical students in the survey, with a greater proportion of women (87\%) being sponsored by their parents compared with men $(78 \%)$. More than three quarters of the participants felt they owed no allegiance to the government of Ghana based on their fee-paying status, with the proportion of women (86\%) higher compared with men (79\%). Seventy percent $(70 \%)$ of non-fee-paying compared with $95 \%$ of fee-paying students felt they owed no allegiance to the Government.

\section{Migration intentions}

As indicated in Table 2, approximately half (49\%) of the medical students surveyed had intentions of migrating after school. Almost half (48\%) of those who intend migrating plan on doing so immediately after completing their house jobs, while $44 \%$ plan to migrate a year or more afterwards. The most popular destination chosen by the potential migrant doctors was North America (38\%), followed by Europe (13\%).

Table 2 Migration intentions

\begin{tabular}{|l|l|l|}
\hline Intentions & Frequency & $\%$ \\
\hline Intend to migrate) & & \\
\hline Yes & 194 & 49.1 \\
\hline No & 199 & 50.9 \\
\hline Total & 393 & 100 \\
\hline *Intended destination & & \\
\hline North America & 74 & 38.1 \\
\hline Europe & 26 & 13.4 \\
\hline North America/Europe & 21 & 10.8 \\
\hline Not sure & 56 & 28.9 \\
\hline Other & 17 & 8.8 \\
\hline Total & 194 & 100 \\
\hline Intended departure & & \\
\hline Before house job & 12 & 6.3 \\
\hline Soon after house job & 92 & 48.4 \\
\hline 1yr after house job & 22 & 11.6 \\
\hline >1yr after house job & 64 & 33.7 \\
Total & 190 & 100 \\
\hline
\end{tabular}

Source: Field work, 2012

*Only those who intend to migrate.

About 11\% would go anywhere between North America and Europe while approximately 9\% chose other destinations. Another $29 \%$ of potential migrant doctors were uncertain about their destinations as at the time of the survey.

\section{Intention to migrate by background characteristics} More than half of those younger than 25 years (55\%) and those aged $30 y e a r s$ or more $(56 \%)$ had intentions of migrating from Ghana after their medical training (see Table 3).
Men (56\%) seemed more likely to have intentions of migrating compared with women (42\%). Medical students from UGMS (61\%) and UCCSMS (60\%) appeared to be more likely to migrate after their training, compared with just about a quarter of their counterparts in UDSMHS. Intention to migrate after medical training appeared to decrease with increasing level of training, with a higher proportion (54\%) among those in level 400 .

Table 3 Intention to migrate by background characteristics

\begin{tabular}{|l|l|}
\hline Characteristics & $\begin{array}{l}\text { Intend to migrate } \\
(\mathrm{n}=194) \%\end{array}$ \\
\hline Age & \\
\hline $20-24$ & 54.9 \\
\hline $25-29$ & 31.9 \\
\hline $30+$ & 55.6 \\
\hline Marital status & \\
\hline Single & 55.5 \\
\hline Married & 42.3 \\
\hline Medical school & \\
\hline UG MS & 61.3 \\
\hline KNUST SMS & 44.0 \\
\hline UDS SMHS & 26.8 \\
\hline UCC SMS & 60.0 \\
\hline Level & \\
\hline 400 & 54.2 \\
\hline 500 & 53.6 \\
\hline 600 & 39.1 \\
\hline Fee Status & \\
\hline Non fee paying & 41.1 \\
\hline Fee paying & 58.6 \\
\hline Sponsor & \\
\hline Self & 50.0 \\
\hline Guardian & 47.2 \\
\hline Parents & 50.2 \\
\hline Other & 38.5 \\
\hline $\begin{array}{l}\text { Allegiance to govern- } \\
\text { ment }\end{array}$ & \\
\hline No & 52.2 \\
\hline Yes & 35.2 \\
\hline Sourc: & \\
\hline
\end{tabular}

Source: Field work, 2012. \% indicates proportion within each category who intend to migrate

As hypothesized, a greater proportion of fee paying students (57\%) compared with non-fee paying students (41\%) had intentions of migrating after their medical training. Half of the self-sponsored students, and those being sponsored by their parents had intentions of migrating after their medical training. Those who felt $(52 \%)$ they owe no allegiance to the government of Ghana based on their fee-paying status were more likely to have intentions of migrating after their training compared with their counterparts who felt otherwise. 
Table 4 Results of logistic regression on intent to migrate and non-allegiance to government

\begin{tabular}{|c|c|c|c|c|}
\hline \multirow[b]{2}{*}{ Characteristics } & \multicolumn{2}{|c|}{ Intend to migrate } & \multicolumn{2}{|c|}{$\begin{array}{l}\text { Non allegiance to govern- } \\
\text { ment }\end{array}$} \\
\hline & $\begin{array}{l}\text { Model } 1 \\
\text { OR } \quad(95 \% \\
\text { CI })\end{array}$ & $\begin{array}{l}\text { Model } 2 \\
\text { OR } \quad(95 \% \\
\text { CI })\end{array}$ & $\begin{array}{l}\text { Model } 3 \\
\text { OR } \quad(95 \% \\
\text { CI })\end{array}$ & $\begin{array}{l}\text { Model } 4 \\
\text { OR } \quad(95 \% \\
\text { CI })\end{array}$ \\
\hline \multicolumn{5}{|l|}{ Fee status } \\
\hline Non fee paying & 1.0 & 1.0 & 1.0 & 1.0 \\
\hline Fee paying & $\begin{array}{l}2.02 * * \\
(1.35,3.02)\end{array}$ & $\begin{array}{l}2.11 * * \\
(1.32,3.38)\end{array}$ & $\begin{array}{l}0.89 * * * \\
(4.13,19.23)\end{array}$ & $\begin{array}{l}9.66^{* * *} \\
(4.42, \\
21.12)\end{array}$ \\
\hline \multicolumn{5}{|l|}{ Age } \\
\hline $20-24$ & 1.0 & 1.0 & 1.0 & 1.0 \\
\hline $25-29$ & $\mathrm{~N} / \mathrm{a}$ & $\begin{array}{l}0.37 * * \\
(0.20,0.68)\end{array}$ & $\mathrm{N} / \mathrm{a}$ & $\begin{array}{l}0.66 \\
(0.31,1.39)\end{array}$ \\
\hline $30+$ & $\mathrm{N} / \mathrm{a}$ & $\begin{array}{l}0.63 \\
(0.12,3.32)\end{array}$ & $\mathrm{N} / \mathrm{a}$ & $\begin{array}{l}0.42 \\
(0.37,4.91)\end{array}$ \\
\hline \multicolumn{5}{|l|}{ Sex } \\
\hline Men & $\mathrm{Na}$ & 1.0 & $\mathrm{Na}$ & 1.0 \\
\hline Women & $\mathrm{N} / \mathrm{a}$ & $\begin{array}{l}0.56^{*} \\
(0.36,0.87)\end{array}$ & $\mathrm{N} / \mathrm{a}$ & $\begin{array}{l}1.56 \\
(0.87,2.78)\end{array}$ \\
\hline \multicolumn{5}{|l|}{ Marital status } \\
\hline Single & $\mathrm{N} / \mathrm{a}$ & 1.0 & $\mathrm{~N} / \mathrm{a}$ & 1.0 \\
\hline Married & $\mathrm{Na}$ & $\begin{array}{l}1.04 \\
(0.46,2.34)\end{array}$ & $\mathrm{N} / \mathrm{a}$ & $\begin{array}{l}1.62 \\
(0.47,5.60)\end{array}$ \\
\hline \multicolumn{5}{|l|}{ Level } \\
\hline 400 & $\mathrm{~N} / \mathrm{a}$ & 1.0 & $\mathrm{~N} / \mathrm{a}$ & 1.0 \\
\hline 500 & $\mathrm{~N} / \mathrm{a}$ & $\begin{array}{l}0.82 \\
(0.48,1.42)\end{array}$ & $\mathrm{N} / \mathrm{a}$ & $\begin{array}{l}1.05 \\
(0.52,2.11)\end{array}$ \\
\hline 600 & $\mathrm{~N} / \mathrm{a}$ & $\begin{array}{l}0.71 \\
(0.41,1.24)\end{array}$ & $\mathrm{N} / \mathrm{a}$ & $\begin{array}{l}1.39 \\
(0.68,2.83)\end{array}$ \\
\hline Psuedo R2 & 0.0709 & 0.0751 & 0.1254 & 0.0709 \\
\hline Wald chi2 (df) & $11.78(1)$ & $35.84(7)$ & $31.14(1)$ & $33.97(7)$ \\
\hline Prob chi2 & 0.000 & 0.000 & 0.000 & 0.000 \\
\hline $\mathrm{N}$ & 375 & 375 & 377 & 377 \\
\hline
\end{tabular}

\section{Multivariate analysis}

This section (see Table 4) addresses the main hypotheses that fee paying students are significantly more likely than non-fee paying medical students to have intentions of migrating after school; and are significantly more likely to feel they owe no allegiance to the government of Ghana based on their fee status, net of other factors.

As shown in Model 1, fee paying medical students were two times more likely $(\mathrm{OR}=2.0, \mathrm{p}=0.001)$ than their non-fee paying counterparts to have intentions of migrating after their medical training. The inclusion of background factors in Model 2 did not change the direction or strength of association between fee paying medical students and intention to migrate; neither did it change the statistical significance.

Among the factors introduced in Model 2, a negative but significant association was found between intention to migrate and those aged 25-29 $(\mathrm{OR}=0.37, \mathrm{p}=$ $0.001)$, as well as women $(\mathrm{OR}=0.57, \mathrm{p}=0.010)$. In other words, students aged 20-24 are 2.7 times more likely to migrate than those aged 25-29, whilst men are 1.8 times more likely than women to migrate.

A similar procedure was followed in addressing the hypothesis that fee paying medical students are significantly more likely to feel they owe no allegiance to the government of Ghana. Again this was confirmed as shown in Models 3 and 4. With only fee status in Model 3, a very strong and significant association was found between fee status and non-allegiance to the government of Ghana based on fee status. Fee paying medical students were about nine times more likely $(\mathrm{OR}=8.91, \mathrm{p}=0.000)$ to feel they owe no allegiance to the government of Ghana based on their fee status. The association became stronger $(\mathrm{OR}=9.66, \mathrm{p}=$ $0.000)$ when background factors were fitted in Model 4. None of the background factors considered in the model was statistically significant.

\section{DISCUSSION}

This study suggests that the students' fee-paying status does affect their intentions to migrate after the completion of their training. This is a relatively new and emerging factor to be considered (in addition to the traditional post-graduation 'pull' and 'push' factors) in strategies aimed at curbing excessive health worker migration. In the currently widely favoured neo-liberal economic model, the trend is for more and more central governments to gradually shift from a fully public funded tertiary education through shared funding, and on to full fee paying training. In the study by WHOAFRO, the reasons given by health personnel for their intention to emigrate from Ghana largely centered on socio-economic and professional development issues. ${ }^{10}$

Whilst several studies have looked at the brain drain in Africa and the migration of doctors, we found none that specifically attempted to understand the role of educational funding mechanisms in influencing the desire to migrate. This study argues that the seeds of flight are now being shown a lot earlier, with those who have funded their own education intending to leave well before even experiencing the traditional push factors. At the time of previous studies, fee payment was not an issue as it is today in local medical education and was not considered as a factor in their final analysis ${ }^{8,16}$ 
This study found a similar percentage of medical students having the intention to migrate compared with earlier work done among actual graduates of Ghanaian Medical schools (49\% in this study versus 50\% 4.5 years after graduation ${ }^{8}$ ). This appears higher than the average found in a study of medical students from six African countries (excluding Ghana) where about one fifth $(21 \%)$ intended to relocate outside sub-Saharan Africa. ${ }^{17}$ Our work however reveals that North America has become the preferred choice of destination for Ghanaian students compared with the other studies ${ }^{8,10}$ which found Europe to be the most popular destination.

Our findings however, contrasted with those of Huntington et al. in Nepal ${ }^{18}$ where students on Government scholarships were no more likely to practice in Nepal than fee paying students at private medical schools. Our findings also differ from Bailey's work in Mala$\mathrm{wi}^{19}$ where all the students sampled indicated a desire to emigrate (with the hope of eventually returning to work in Malawi).

The students in the Malawi study had their medical education at least partly publicly funded through donor funding and Government subsidized fees. Similarly, high emigration intentions (95.5\% of respondents) were also found among Lebanese medical students ${ }^{20}$. In a peculiar twist, fee paying medical students in Karachi, Pakistan were less likely to consider a career abroad compared to merit students. ${ }^{21}$ These international differences are to be expected given differing socio-economic climates and cultural attitudes towards migration between countries. It underpins the need for ongoing, specific, country- based research to understand the magnitude of the problem in each case and to understand its evolving driving forces.

The reasons for the findings that the students aged 2024 are 2.7 times more likely to migrate than those aged 25-29 and that men are 1.8 times more likely to migrate than women are not very clear from this study. More research is needed to clarify this finding.

The Government of Ghana has made some progress in addressing the traditional push factors that saw the mass exodus of doctors in the past, including going some way in addressing remuneration, adding other economic incentives, and providing a means of local postgraduate training, with the establishment of the Ghana College of Physicians and Surgeons.

The trend towards an increasing proportion of feepaying students enrolled into medical schools and establishing medical schools that enroll only fee paying students may undermine some of the progress made in years past. Inferences to be drawn from the finding of a lack of allegiance to the government of Ghana based on their fee status, would include, a likely unwillingness to serve in otherwise deprived areas and less likelihood to serve in the public sector.

Whilst it seems inevitable that more and more of the burden of funding tertiary education is likely to fall on the shoulders of students and their families, it might be prudent for developing countries like Ghana to explore funding mechanisms that are less likely to add to the push factors that make physician retention difficult after graduation. Further follow-up work is planned to see how assessed intentions have translated into actual behaviour.

\section{REFERENCES}

1. Wright D, Flis N, and Gupta M. The 'Brain Drain' of physicians: historical antecedents to an ethical debate. Philos Ethics Humanit Med. 2008; 3:24

2. Jahangir AK. Migration of health personnel and its impact on health systems in developing countries. JAMC 19(4): Oct-Dec 2007

3. World Health Assembly. International migration of health personnel: a challenge for health development, Resolutions and Decisions, WHA57.19 2005

4. Wort UC. Choosing Prayer camps over a visit to the doctor. Mercy Corps. http://www.globalenvision.org/2009/02/09/. Accessed February 1, 2013

5. Kanna MA. From brain drain to brain circulation. Jos Journal of Medicine 2009, Vol.4.No.1: African Journals http://dx.doi.org/10.4314/jim.v4i1.55092. Accessed 24/12/2013.

6. Tapsoba SJM, Hounou PV, Meera S. Brain drain and capacity building in Africa. ECA/IDRC/IOM,20.Available at bnc.idrc.ca/dspace/bitstream/10625/28020/1/11814 9.pdf .Accessed 27/12/2013

7. Dovlo D. The brain drain and retention of health professionals in Africa. A case study prepared for a regional Training conference on improving tertiary education in sub-saharan Africa. Things that work 2003.

8. Dovlo D, Nyonator F. Migration of Graduates of the University of Ghana Medical School: A Preliminary Rapid Appraisal Human Resources for Health Development Journal 1999;3 (1):34-37

9. Shah A. "Brain Drain of Workers from Poor to Rich Countries." Global Issues. 2006;http://www.globalissues.org/article/599/. Accessed October 14, 2011.

10. Awases M, Gbary A, Nyoni J, \& Chatora R, , Migration of Health Professionals in Six Countries: A Synthesis Report. Brazzaville, Congo: World 
Health Organization-Africa Regional OfficeDepartment of Health Systems (AFRO DHS). November 2003.

11. Higher Education Finance and Cost Sharing in Ghana:

http://gse.buffalo.edu/org/inthigheredfinance/files/ Country Profiles/Africa/Ghana.pdf. Accessed 18/04/2013

12. University of Ghana: http;//www.ug.edu.gh/aad/docs/fees1314/20132014-FEES. Accessed 24/12/13.

13. Kwame Nkrumah University of Science and Technology. http:/www.knust.edu.gh/admissions Accessed 24/12/13.

14. University for Development studies. Admission: Undergraduates fees. University for Development Studies, http://www.uds.edu.gh/undergradfees.php. 2012/2013. Accessed 24/12/13.

15. University of Cape Coast: http://www.ucc.edu.gh/admissions/tuition-andfees-2013-2014. Accessed 24/12/13.

16. Hagopiana A, Ofosu A, Fatusi A, Biritwum R, Essele A. Harta G, Watts C. The flight of physicians from West Africa: Views of African physicians and implications for policy. Social Science \& Medicine 61 (2005) 1750-1760
17. Burch VC, McKinley D, Van-Wyk J, KiguliWalube S, Cameron D, Cilliers FJ, Longombe AO, Mkony C, Okoromah C, Otieno-Nyunya B, Morahan PS. Career intentions of medical students trained in six sub-Saharan African countries. Educ Health 2011; 24(3):614.

18. Huntington I, Shrestha S, Reich NG, Hagopian A. Career intentions of medical students in the setting of Nepal's rapidly expanding private medical education system. Health Policy and Planning 2011;1-12

19. Bailey N, Mandeville KL, Rhodes T, Mipando M, Muula AS. Postgraduate career intentions of medical students and recent graduates in Malawi: a qualitative interview study. BMC Medical Education 2012;12:87

20. Akl EA, Maroun N, Major S, Afif C, Abdo A, Choucair J, Sakr M, Li C, Grant BJB, Schünemann HJ. Post-graduation migration intentions of students of Lebanese medical schools: a survey study. BMC Public Health 2008, 8: 191

21. Sheikh A, Naqvi SHA, Sheikh K, Bandukda MY. Physician migration at its roots: a study on the factors contributing towards a career choice abroad among students at a medical school in Pakistan. Globalization and Health 2012, 8:43 